\title{
The "Promise" of Ratification: A Ugandan-EAC Perspective
}

\author{
Adv. Steven Serumaga- Zake \\ North-West University (RSA) \\ stevenzake@yahoo.com
}

\section{Dr. Mwanawina llyayambwa}

North-West University (RSA) mwanawinai@gmail.com

\section{Doi:10.5901/mjss.2014.v5n20p2172}

\section{Abstract}

\begin{abstract}
International law functions on the basis that nations or institutions that are signatories to international law instruments will abide by certain uniform standards of behaviour or principles. The Republic of Uganda is a member state to the African Union and the East African Community. These organizations have made the protection of human rights one of the pillars of their existence and further place an obligation on their member states to adhere to universally acceptable principles of good governance, democracy, the rule of law, observance of human rights and social justice. The Government of Uganda has also done good in ratifying various human rights instruments at both regional and continental occasions. Despite this, the human rights record of Uganda remains very low according to various Human rights Reports including those by Amnesty International and Human Rights Watch. The crux of this paper is to investigate the effect of ratification on the adjudication of human rights related disputes within the Republic of Uganda. It does so by analyzing various judgments of the Constitutional Court of Uganda and of the East African Court of Justice. Its main findings are that the EAC Court of Justice has been proactive in promoting the international law obligations of Uganda in its decisions however the Constitutional Court of Uganda is yet to reveal its position on developing the international human rights jurisprudence of the country.
\end{abstract}

Keywords: Uganda, East African Community, ratification, human rights

\section{Introduction}

The Republic of Uganda is a member state to the African Union (AU) and the East African Community (EAC). The Constitutive Act of the AU as the principal founding document of the African Union articulates that member states should promote and protect human and peoples' rights in accordance with the African Charter on Human and Peoples' Rights and other relevant human rights instruments. ${ }^{1}$ The Treaty establishing the $(E A C)^{2}$ also places emphasis on the protection of human rights ${ }^{3}$ and further establishes the East African Court of Justice under Article 33. The mandate of the court includes amongst others, the adjudication and interpretation of human rights related disputes. The EAC Treaty further places an obligation on its member states to abstain from any measures that are likely to stifle the attainment of the principles and objectives of the Community. ${ }^{4}$ Of late, international law principles have been used to determine important factors such as the standard of a country's democracy, the level of the country's respect for and observance of human rights, the future stand of the country's political environment and sometimes the country's eligibility to financial help from international funding bodies such as the International Monetary Fund (IMF) and the World Bank. ${ }^{5}$ Because of such political, economic and social advantages attached to a country's being part of the international community, like many countries, Uganda has since independence not only signed and ratified a number of regional and continental human rights instruments ${ }^{6}$ but went as far as adopting a Constitution that embraces provisions that call for the respect for and

${ }^{1}$ Constitutive Act of the AU, 2000. Art 3(a)-(n).

${ }^{2}$ Treaty Establishing the East African Community (EAC, 1999/2000).

${ }^{3}$ Art 3(3)(b).

${ }^{4}$ Art 8(1)(c).

${ }^{5}$ See Bratton, M., Lambright, G., \& Sentamu, R. (2000). Democracy and economy in Uganda: a public opinion perspective. Inst. for Democracy in South Africa.

${ }^{6}$ See Moorehead, A., \& Rone, J. (2005). Uprooted And Forgotten: Impunity And Human Rights Abuses in Northern Uganda. Also see OHCHR, 'Report on the work of the Office of the High Commissioner for Human Rights in Uganda', UN doc A/HRC/4/49/Add.2 (2007), at para 31. Uganda has also ratified the African Charter on Human and Peoples' Rights ('ACHPR'); the African Charter on the Rights and Welfare of the Child; the OAU Convention on Specific Aspects of Refugee Problems; and the Protocol to the ACHPR on the Establishment of an African Court on Human and Peoples' Rights to which Ugandan Supreme Court Justice, George W Kanyeihamba was elected a judge on 22 January 2006. 
observance of such international law obligations. ${ }^{7}$ Uganda is also a signatory to the Cotonou Agreement which obligates it to promote and protect democratic principles and the rule of law. ${ }^{8}$

The Constitution of the Republic of Uganda guarantees that the State shall respect institutions which are charged with the responsibility for protecting and promoting human rights as well as respecting the independence of nongovernmental organisations which protect and promote human rights. ${ }^{9}$ The Constitution in Chapter 4 , further engraves a Bill of Rights similar in architecture to that of the United Nations Universal Declaration of Human Rights. The enforcement of these rights is secured in Section 50 of the Constitution which directs that a person who claims that a fundamental or other right or freedom guaranteed under the Constitution has been infringed or threatened is entitled to apply to a competent court for redress. ${ }^{10}$

Although there is a clear existence of the above, various regional and international human rights agencies have noted that three most serious human rights problems in the country were a lack of respect for the integrity of the person (including unlawful killings, torture, and other abuse of suspects and detainees); unwarranted restrictions on civil liberties (including freedom of assembly, the media, and association); and violence and discrimination against marginalized groups such as women (including female genital mutilation/cutting (FGM/C), children (including victims of sexual abuse and ritual killing), persons with disabilities, and the lesbian, gay, bisexual, and transgender (LGBT) community. ${ }^{11}$ This work is further warranted by the fact that there is currently a mixed analysis on Uganda's human rights reflection. Whilst Amnesty International, the World Bank and United Nations are not satisfied with human rights efforts in the country, other authors and press releases have hailed it as a "success story", ${ }^{12}$ making the country to appear to many as the most democratic and human rights respecting state in the east and central part of the African continent. ${ }^{13}$

This paper will not attempt to statistically quantify the nature of human rights violations in Uganda but rather establish whether the ratification of human rights norms by Uganda has impacted on judicial bodies positively in the manner in which they adjudicate human rights. The Judicial bodies referred to in this work are the Constitutional Court at domestic level and the East African Court of Justice at international law level.

\section{The East African Community}

The birth of the EAC can be found in the grand ideals of the Organisation of African Unity (OAU) to promote regional integration on the African continent. The Council of Ministers of the OAU in their Resolution 464 on the Division of Africa into Five Regions resolved to divide Africa into five regional areas..$^{14}$ The subsequent Treaty establishing the African Economic Community was signed in $1991 .{ }^{15}$ In the 2006 African Union Banjul Summit resolved to recognize eight (8) Regional Economic Communities on the African continent of which one of them was the EAC. ${ }^{16}$

The EAC is the regional inter-governmental organisation of the Republics of Burundi, Kenya, Rwanda, Uganda and the United Republic of Tanzania. The Treaty for the Establishment of the EAC was signed on 30th November 1999 and entered into force on 7th July 2000, following its ratification by the three original partner states, Kenya, Uganda and Tanzania. The Republic of Burundi and the Republic of Rwanda acceded to this EAC Treaty on 18th June 2007 and became full members of the Community with effect from 1st July 2007. ${ }^{17}$

Article 9 of the Treaty of the EAC establishes that the East African Court of Justice is the judicial organ of the community. Judges of the Court are appointed by the Summit from among persons recommended by the Partner States who are of proven integrity, impartiality and independence and who fulfil the conditions required in their own countries for

\footnotetext{
${ }^{7}$ The Preamble of the Uganda Constitution of 1995 xxviii states that, foreign policy of Uganda shall be based on the principles of: (b) respect for international law and treaty obligations, (d) settlement of international disputes by peaceful means,

${ }^{8}$ Article 9 provides that 'respect for human rights and fundamental freedoms, including respect for fundamental social rights, democracy based on the rule of law and transparent and accountable governance are an integral part of sustainable development. ${ }^{9}$ Art V(i)-(ii)

$10 \operatorname{Sec} 50$

${ }^{11}$ Amnesty International, (2013) The World Bank, World Development Indicators 2013 [Online] Available: http://www.amnesty. org/en/region/uganda (May 8, 2014) and United Nations Development Programme, (2013), Uganda Country Report [Online] Available http://www.bti-project.org/fileadmin/Inhalte/reports/2014/pdf/BTI\%202014\%20Uganda.pdf (June 2, 2014).

12 McKinley, James, (1997), Uganda Leader Stands Tall in New African Order, , New York Times.

${ }^{13}$ Hauser, E. (1999). Ugandan relations with Western donors in the 1990s: what impact on democratisation?. The Journal of Modern African Studies, 37(04), 621-641. ${ }^{14} \mathrm{CM} / \mathrm{Res} .464(\mathrm{XXVI})$

${ }^{15}$ North Africa: West Africa : South Africa; East Africa and Central Africa.

${ }^{16}$ The 8 groups included a) The Southern African Development Community (SADC), The Arab Maghreb Union (AMU), The Community of Sahel-Saharan States (CEN-SAD), The Common Market for Eastern and Southern Africa (COMESA), The East African Community (EAC), The Economic Community of West African States (ECOWAS), The Economic Community of Central African States (ECCAS) and The Inter-Governmental Authority on Development (IGAD). Other groups not recognised by the AU but still in existence are the African Financial Community (CFA), Common Monetary Area (CMA), Economic and Monetary Community of Central Africa (CEMAC), Indian Ocean Commission (IOC), Southern African Customs Union (SACU), West African Economic and Monetary Union (UEMOA), and the West African Monetary Zone (WAMZ).

${ }^{17}$ EAC Treaty, note 2.
} 
the holding of such high judicial office, or who are jurists of recognised competence, in their respective Partner States. ${ }^{18}$ The jurisdiction of the Court extends to the interpretation and application of the EAC Treaty. ${ }^{19}$ The architecture of the Treaty also makes it possible for Partner States, the Secretary General, legal and natural persons and employees of the EAC to bring cases to the Court. ${ }^{20}$ Similar to the text of the Common Market for Eastern and Southern Africa (COMESA) Court of Justice, member states are required to take, without delay, the measures required to implement a judgment of the Court. ${ }^{21}$

The EAC Treaty establishes that human rights are one of the core principles upon which the Community is established. ${ }^{22}$ By ratifying the Treaty establishing the EAC, member states have thereby undertaken to abide by the principles of good governance, including adherence to the principles of democracy, the rule of law, social justice and the maintenance of universally accepted standards of human rights. ${ }^{23}$ Human rights have been defined as rights that are inherent to all human beings and are afforded without discrimination. They are universal legal guarantees protecting individuals and groups against actions and omissions that interfere with fundamental freedoms, entitlements and human dignity. ${ }^{24}$

Universal human rights are often expressed and guaranteed by law, in the form of international agreements, customary international law, general principles and other sources of international law. International human rights law such as the AU's African Charter on Human and Peoples' Rights ${ }^{25}$ lays down obligations of governments to act in certain ways or to refrain from certain acts, in order to promote and protect human rights and fundamental freedoms of individuals or groups.

\section{Ratification in International Law}

Ratification is an act by which a state signifies an agreement to be legally bound by the terms of a particular treaty. To ratify a treaty, the State first signs it and then fulfils its own national legislative requirements. ${ }^{26}$ During the time period between ratification and the transformation of its domestic legislation, a state party to a treat is prohibited from performing any acts that may defeat or contravene the spirit of the ratified treaty. ${ }^{27}$ The importance and impact of ratification is critical to the application of international law. In instances where a dispute arises, ordinary citizens may then be able to hold the State accountable through its international law obligations. A standard example of such within the African context is the case of Longwe $v$ Intercontinental Hotels Limited. 28

The facts in the Longwe case are that the complainant, a human rights and gender activist in Zambia, had gone to Lusaka's Intercontinental Hotel with her partner. At the Hotel, Sara's partner remained in the car in the garage while she went to the hotel to look for a friend. She was refused access by Hotel security on the grounds that she was not accompanied by a male partner. Hotel policy dictated that it would disallow access to certain parts of the Hotel to unaccompanied women. ${ }^{29}$ The restriction did not apply to unaccompanied men. In a bid to fight what she saw as discrimination based on gender and sex contrary to the non-discrimination clause in Section 23 of the Zambian Constitution, the applicant decided to petition the High Court. She argued that besides article 23 of the Constitution, the conduct of the Hotel constituted discrimination from which she was protected under the Convention on the Elimination of all Forms of Discrimination against Women (CEDAW) and the African Charter on Human and Peoples' Rights. The respondent (Intercontinental Hotels Limited) averred that the petitioner had no right to cite conventions which Zambia had not yet domesticated in local law and which the Court, therefore, had no jurisdiction to apply. However, the Court was alive to its discretion to apply the undomesticated conventions which the country had ratified. In the court's ruling, Musumali. J., held as follows:

It is my considered view that ratification of such documents by a nation state without reservations is a clear

${ }^{18}$ EAC Treaty, note 2, Art 24(1)

${ }^{19} E A C$ Treaty, note 2, Art 23.

${ }^{20}$ See EAC Treaty, note 2, Art 28-31. Also note that under Art 36(1) The Summit, the Council or a Partner State may request the Court to give an advisory opinion regarding a question of law arising from this Treaty which affects the Community, and the Partner State, the Secretary General or any other Partner State shall in the case of every such request have the right to be represented and take part in the proceedings.

${ }^{21}$ EAC Treaty, note 2. Art 38. See also Art 44 which provides that the execution of a judgment of the Court which imposes a pecuniary obligation on a person shall be governed by the rules of civil procedure in force in the Partner State in which execution is to take place. The order for execution shall be appended to the judgment of the Court which shall require only the verification of the authenticity of the judgment by the Registrar whereupon, the party in whose favor execution is to take place, may proceed to execute the judgment. ${ }^{22} \operatorname{Art} 3(3)(b)$

${ }^{23}$ Art 7(2).

${ }^{24}$ Landman, T., \& Carvalho, E. (2009). Measuring human rights. Routledge.

${ }^{25}$ Adopted in 1981.

${ }^{26}$ See Reuter, P. (1995). Introduction to the Law of Treaties. Routledge.

27 See Art. 18 of the Vienna Convention.

${ }^{28}$ Sara Longwe v Intercontinental Hotels 1992/HP/765 19934 LRC 221.

${ }^{29}$ See summary of facts in Sara Longwe v Intercontinental Hotels 1992/HP/765 19934 LRC 221. 
testimony of the willingness of the State to be bound by the provisions of such a document. Since there is willingness, if an issue comes before court which would not be covered by local legislation but would be covered by such international document, I would take judicial notice of that treaty or Convention in my resolution of the dispute. ${ }^{30}$

The case was decided in favour of the complainant. It is important to note that in the Sara Longwe judgement, the presiding officer of a domestic court in Zamibia was willing to assert the position of an undomesticated but ratified human rights instrument against the practice of the hotel. This will later be contrasted against the interpretative practices of the Constitutional Court of Uganda. Similar cases following such assertive interpretation include the South African cases of Hoffman $v$ South African Airways, ${ }^{31} \mathrm{~K} v \mathrm{~K},{ }^{32}$ and the landmark decision of $S$ v Makwanayane. ${ }^{33}$ In the Hoffman case, the Court opined that the need to eliminate unfair discrimination did not arise only from Chapter 2 of the South African Constitution but also arose out of international obligations since South Africa had ratified a range of anti-discrimination Conventions, including the African Charter on Human and Peoples' Rights. ${ }^{34}$ The $K \vee K$ decision concerned an application for the return of an abducted minor child to the jurisdiction of the Court of its habitual residence. The Court took into account the fact that South Africa had ratified the United Nations Convention on the Rights of the Child ${ }^{35}$ and as such was bound to give effect to Article $3(1)^{36}$ of the Convention.

It is submitted that these cases represent the ideal interpretation and application of international law. Citizens should be able to find recourse through international standards even when the domestic laws are not clear on the application of human rights norms.

\title{
4. Ratification from an EAC Perspective
}

The Parliament of Uganda ratified the Treaty establishing the EAC on April 27, 2000 in accordance with Article 123 of the Constitution, Section 3 (b) (ii) of the Ratification of Treaties Act, ${ }^{37}$ and Article 152 of the Treaty. By doing such, Uganda has signalled its intention to support the objectives and principles outlined in the EAC Treaty.

One of the fundamental principles of the rule of law and human rights is to ensure that interested persons should have recourse against judicial or administrative decisions that affect them. This principle was rightly upheld in Sebalu $v$ The Attorney General of the Republic of Uganda ${ }^{38}$ in which the court heard an application seeking to declare that Uganda's inability to meet a deadline for submitting written comments on the draft protocol to operationalize the extended jurisdiction of the EAC Court was a failure by Uganda to ensure that affected persons may appeal decisions of the Court. The Court, relying on instruments that Uganda had ratified, concluded that the 'delay to extend the appellate jurisdiction in the then circumstances was a contravention of the fundamental principles of good governance, freedoms and rights, thereby infringing the Treaty. ${ }^{\prime 39}$ The EAC was thereafter advised by the Court to take corrective measures against the Ugandan government.

In Mohochi v. Attorney General of Uganda, ${ }^{40}$ the domestic laws of Uganda aimed at immigration control were contested against the Treaty objectives aspiring to promote the free movement of persons, labour, and services within the region. In summary, the Court concluded that the National Citizenship and Immigration Control Act of Uganda contained provisions that defeated the aims of the EAC. In particular, Section 52 of the Act was pronounced to be inconsistent with Uganda's treaty objectives since it also denied persons the right to fair and just administrative action, the right to information and freedoms of assembly, association and movement guaranteed by the EAC Treaty and other relevant human rights instruments. The Court ordered that:

\begin{abstract}
...on matters pertaining to citizens of the Partner States, any provisions of Section 52 of Uganda's Citizenship and Immigration Control Act formerly inconsistent with provisions of the Treaty and the Protocol were rendered inoperative and have no force of law, as of the respective dates of entry into force of the Treaty and the Protocol as law applicable in the Republic of Uganda.
\end{abstract}

\footnotetext{
${ }^{30}$ Sara Longwe, Ibid note

${ }^{31} 2001$ (1) SA 1.

321999 (4) SA 691.

331995 (3) SA 391. See para 33-39 in which a substantial portion of the judgment was devoted to canvassing South Africa's international law obligations. ${ }^{34}$ at para 51.

351989 .

${ }^{36}$ In all actions concerning children, whether undertaken by public or private social welfare institutions, courts of law, administrative authorities or legislative bodies, the best interests of the child shall be a primary consideration.

371998.

${ }^{38}$ Ref. No. 1 of 2010, Judgment (EACJ, Jun. 30, 2011)

${ }^{39}$ at pp 30.

40 Judgment, Ref. No. 5 of 2011 (EACJ, May 17, 2013)
} 
From the above cases, it is illustrative that the court relied on the EAC Treaty that Uganda had ratified as a direct source of law in establishing the obligations of Uganda. The EAC Court of Justice has been consistent in interpreting treaty obligations over domestic arrangements. In another case that did not involve Uganda, the Court in Peter Anyang' Nyongo and Others $v$ The Attorney General of the Republic of Kenya and Others ${ }^{41}$ held that the rules invoked by the Kenya National Assembly for purposes of electing members to the East African Legislative Assembly, which did not allow election directly by citizens or residents of Kenya or their elected representatives was null and void and further contrary to the provisions of the EAC Treaty which required that such elected members shall not be members of the Kenyan Legislature but shall represent as much as it is feasible, the various political parties represented in the National Assembly. In finding in favour of the Applicants, the Court emphasised that domestic law shall be subordinate to the EAC Treaty and that;

..while the Treaty upholds the principle of sovereign equality, it must be acknowledged that by the very nature of the objectives they set out to achieve, each Partner State is expected to cede some amount of sovereignty to the Community and its organs albeit in limited areas to enable them play their role. ${ }^{42}$

From the above cases, it is evident that the Court has not been shy of correctly placing the EAC Treaty obligations that Uganda has ratified as superior to its domestic legislation or arrangements.

\section{Domestic Interpretation of Ratification}

The Constitution of Uganda is the supreme law of the republic and further provides that all law or custom that is inconsistent with it is invalid. ${ }^{43}$ The foreign policy objectives listed in the Constitution include, amongst others the respect for international law and treaty obligations. ${ }^{44}$ It can then be argued that the Constitution places an obligation on the state authorities and institutions to ensure that they respect the international agreements that Uganda has willingly entered into. The Ratification of Treaties Act provides procedures that are to be followed in order for a treaty to be ratified in accordance with article 123 of the Constitution. The power to ratify a treaty is vested in the cabinet but such a treaty would have to be laid out before parliament "as soon as possible", otherwise if according to the opinion of the attorney general the treaty will require an amendment to the Constitution, then it has to be ratified by Parliament. Though this framework may seem permitting to bind Uganda with international law obligations at domestic level, the Judicature Act ${ }^{45}$ which consolidates and revises provisions of the Constitution in relation to interpretation, jurisdiction etc does not make any reference to international law or treaties when listing the sources of law. This is unlike the South African position wherein the Constitution specifically states that when interpreting the Bill of Rights courts must consider international law.

This gap relating to international law is evident in cases such as Uganda Association of Women Lawyers and Others $v$ Attorney General ${ }^{46}$ and Soon Yeon Kong Kim and Another vs Attorney General. ${ }^{47}$ In both cases, the Constitutional Court of Uganda had foregone the opportunity to establish a precedent on the position of international law in relation to domestic legislation. Though the cases did uphold the human rights principles contested, the Court mostly relied on domestic law and in other instances drew comparative analyses with other countries but fail to directly develop the international law jurisprudence of Uganda. This failure to engage in judicial activism is committed by the courts despite the applicants making direct reference to international law in their applications. For instance, in the Yeon Kong Kim case in which the applicant argued that he was denied a fair trial relying on Article 14 of the International Covenant on Civil and Political Rights 1966 and Article 6 of the European Convention for the Protection of Human Rights and Fundamental Freedoms, the Court in arriving at their decision did not submit any expressions or analysis on the issues relating to international law.

In another case, Law \& Advocacy for women in Uganda v Attorney General, ${ }^{48}$ the Constitutional Court had to determine whether the custom and practice of female genital mutilation was unconstitutional and should be declared null and void. The applicants in this matter did make submissions hinged on various findings of United Nations agencies ${ }^{49}$ as well the provisions of the Convention on rights of the Child and the International Covenant on Economic, Social and Cultural Rights (ICESCR) but the Court in their raison d'être omitted to canvass the position of domestic law in contrast to

\footnotetext{
${ }^{41}$ EACJ Reference No. 1 of 2006

${ }^{42}$ Peter Anyang', note 37, p 44.

${ }^{43}$ Art 2.

${ }^{44}$ XXVIII.

${ }^{45}$ Cap 13.

${ }^{46} 2004$ UGCC 1

${ }^{47} 2008$ UGCC 2

482010 UGCC 4

${ }^{49}$ at para 4.
} 
international law. A similar trend is recorded in other cases such as Attorney General v Paul K. Ssemogerere and Anor, ${ }^{50}$ Shabahuria Matia v Uganda - Criminal Revisiona ${ }^{51}$ and Muwanga Kivumbi vs Attorney General.52 In these cases, the Court does take note of the international law instrument being cited by the applicants but does not deliberately form an opinion on how the international law provisions would relate to domestic legislation in view of ratification.

In casu, what can be deduced from these cases is that the nature of judicial interpretation by the Constitutional Court of Uganda finds comfort in relying on domestic provisions as sources of law. The Court fails to depart from the "normally" accepted form of interpretative methodology. ${ }^{53}$

\section{Conclusion}

Having canvassed the selected judgments of the EAC Court of Justice, it is evident that the Court continues to achieve its main responsibility of ensuring the adherence to law through the interpretation and application of the Treaty establishing the East African Community. On several occasions the judgements reflect that the bench is willing to set aside domestic provisions which militate against the community objectives. This from of interpretation is clearly in line with Article 27 of the Vienna Convention on the Law of Treaties which prohibits state parties from invoking internal law as a justification for the breaches. Though the Constitutional Court of Uganda has not erred in the cases cited herein, the fact that the Court does not express itself consciously on whether the international law obligations of Uganda have a direct legal effect, giving rise to a cause of action for citizens when the government fails to fulfil them is a matter that should worry the international community.

\section{References}

Books

Landman, T., \& Carvalho, E. (2009). Measuring human rights. Routledge.

Reuter, P. (1995). Introduction to the Law of Treaties. Routledge.

Journals

Hauser, E. (1999). Ugandan relations with Western donors in the 1990s: what impact on democratisation?. The Journal of Modern African Studies, 37(04), 621-641.

McKinley, James, (1997), Uganda Leader Stands Tall in New African Order, New York Times.

Zarbiyev, F. (2012). Judicial activism in international law-a conceptual Framework for analysis. Journal of International Dispute Settlement, 3(2), 247-278.

Treaties / Instruments

Constitutive Act of the AU, 2000.

Ratification of Treaties Act, 1998.

Treaty Establishing the East African Community, 1999/2000.

Uganda Constitution of, 1995.

United Nations Convention on the Rights of the Child, 1989.

Vienna Convention on the Law of Treaties, 1969.

Cases

Attorney General v Paul K. Ssemogerere and Anor Constitutional Appeal No.3 of 2000

Hoffman v South African Airways 2001 (1) SA 1.

K v K 1999 (4) SA 691.

Law \& Advocacy for women in Uganda v Attorney General 2010 UGCC 4.

Mohochi v. Attorney General of Uganda EACJ Ref. No. 5 of 2011.

Muwang Kivumbi vs Attorney General Constitutional Petition No. 9 of 2005

Peter Anyang' Nyongo and Others v The Attorney General of the Republic of Kenya and Others EACJ Ref No. 1 of 2006.

${ }^{50}$ Constitutional Appeal No.3 of 2000

51 Cause No. MSK 00 CR 0005 OF 1999

52 Constitutional Petition No. 9 of 2005.

53 See Zarbiyev, F. (2012). Judicial activism in international law-a conceptual Framework for analysis. Journal of International Dispute Settlement, 3(2), $247-278$. 
S v Makwanayane 1995 (3) SA 391.

Sara Longwe v Intercontinental Hotels 1992/HP/765 19934 LRC 221.

Sebalu v. The Attorney General of the Republic of Uganda EACJ Ref. No. 1 of 2010.

Shabahuria Matia v Uganda - Criminal Revisional Cause No. MSK 00 CR 0005 OF 1999

Soon Yeon Kong Kim and Another vs Attorney General 2008 UGCC 2.

Uganda Association of Women Lawyers and Others v Attorney General 2004 UGCC 1.

Web Sources

Amnesty International, (2013) The World Bank, World Development Indicators 2013 [Online] Available: http://www.amnesty.org/en/ region/uganda (May 8, 2014).

United Nations Development Programme, (2013), Uganda Country Report [Online] Available http://www.bti-project.org /fileadmin/Inhalte/ reports/2014/pdf/BTI\%202014\%20Uganda.pdf (June 2, 2014). 